\title{
Seropositivity for Trypanosoma cruzi in domestic dogs from Sonora, Mexico
}

\author{
Minerva Arce-Fonseca', Silvia C. Carrillo-Sánchez', Ramón M. Molina-Barrios², Mariana Martínez-Cruz', \\ Jesús R. Cedillo-Cobián², Yuly A. Henao-Díaz ${ }^{2}$ and Olivia Rodríguez-Morales ${ }^{1 *}$
}

\begin{abstract}
Background: Chagas disease is an important health problem in Latin America due to its incapacitating effects and associated mortality. Studies on seropositivity for Trypanosoma cruzi in Mexican dogs have demonstrated a direct correlation between seropositivity in humans and dogs, which can act as sentinels for the disease in this region. The objective of this study was to determine the seropositivity for T.cruzi infection in dogs from Sonora, a northern borderstate of Mexico.
\end{abstract}

Methods: Responsible pet owners were selected at random from an urban area of Empalme municipality, Sonora, Mexico, and from there, 180 dog samples were collected. Anti-T. cruzi antibodies were determined using the enzymelinked immunosorbent assay (ELISA) method. Reactive ELISA sera were processed by indirect immunofluorescence to confirm the presence of anti-T. cruzi antibodies. For the statistical analysis, chi-square tests were conducted.

Results: Dogs' sera showed a seropositivity rate of $4.44 \%$. The rate of seropositivity was not associated with the dogs' age, sex, or socioeconomics pertaining to the geographical area. One sample $(1 / 180,0.55 \%)$ showed the acute state of the disease.

Conclusions: The study found a presence of anti-T. cruzi antibodies in dogs in this area, which suggests vector transmission. There is a need for active surveillance programs throughout the state of Sonora and vector control strategies should also be implemented in endemic regions.

Keywords: Chagas disease, Epidemiology, Reservoir, US-Mexico border dogs, Trypanosoma cruzi, Mexico

\section{Background}

Chagas disease (CD) is caused by the protozoan Trypanosoma cruzi. Because the parasite is distributed in areas ranging from the southern United States [1] to Argentina and Chile, the disease is commonly known as American trypanosomiasis. Epidemiological data from 2010 estimated that there were about 5,742,167 people infected in Latin America and 70,199,360 at risk of acquiring infection. Argentina, Brazil, and Mexico were the three countries with the highest estimated number of infected people $(1,505,235$; $1,156,821$; and 876,458 , respectively) [2]. This disease has been one of the biggest public health problems in Latin America due to its incapacitating effects and associated mortality [3]. Increased international migration has resulted

\footnotetext{
*Correspondence: rm.olivia@gmail.com

${ }^{1}$ Department of Molecular Biology, National Institute of Cardiology "Ignacio Chávez", Juan Badiano No. 1, Col. Sección XVI, Delegación Tlalpan, 14080

Mexico City, Mexico

Full list of author information is available at the end of the article
}

in the disease spreading to non-endemic areas, including Canada, Europe, Asia, and Oceania. Although vector-borne transmission cannot occur outside of America (as the vector is not present), the disease can spread via vertical transmission, blood transfusions, and organ transplantations in non-endemic countries [4-6].

In Mexico, there are no official programs for vector control. In addition, there is no consensus on diagnostic methods for acute and chronic phases of $\mathrm{CD}$, and trypanocidal therapy is rarely administered to chronic patients because the availability of trypanocidal drugs is restricted, and physicians only treat the cardiac or digestive symptoms, as they consider drugs are ineffective in this stage of the disease and have undesirable side effects. The current prevalence of the disease is unknown because there are no official cases reported. However, based on the percentage of seropositivity published by Cruz-Reyes and PickeringLópez in 2006 [7], and considering there are 112.3 million 
inhabitants in Mexico (as according to the 2010 National Population Census [8]), it is possible to estimate that 5.5 million people are at risk of acquiring the $T$. cruzi infection in the country [9].

The transmission cycle includes mammalian reservoirs of the parasite and triatomine species as vectors, which colonize domestic and peridomestic environments. Dogs are considered the most important domestic reservoir of the parasite in the dynamics of $T$. cruzi infection because dogs are an important food source for triatomine bugs and they can also eat infected insects. Thus, it has been demonstrated that infected dogs increase the risk of transmission inside human dwellings [10]. From the veterinary point of view, it is also important to consider that dogs are susceptible to acquire American trypanosomiasis characterized by heart conditions, such as electrical conduction disturbances, and ventricular and supraventricular arrhythmias, as well as secondary signs such as ascites, respiratory distress, thoracic effusion, and cyanosis [11, 12].

It is believed that over $96 \%$ of CD transmission occurs by the vector route [13]. Mexico has one of the most diverse populations of triatomine bugs, with 32 documented
T.cruzi-infected species, establishing them as potential vectors of $\mathrm{CD}$ [14]. Few national studies have estimated the presence of T. cruzi in domestic reservoirs in Mexico. In the state of Sonora, there are no reports about seropositivity for T. cruzi infection in dogs, despite having sufficient case reports in other countries indicating that the presence of this mammal in households can increase the human risk of contracting the disease by up to five times [15].

Studies describing the seropositivity rate in dogs in Mexico (see Table 1) have demonstrated a direct correlation with the presence of antibodies against $T$. cruzi in humans $[10,16-26]$. The high seropositivity rate of $T$. cruzi infection in dogs from different regions in the country suggests that dogs are a potential domestic reservoir and are thus potential perpetuators of the T. cruzi transmission to humans. In Sonora, there is no information about prevention and control programs relating to $C D$, despite it being an endemic area. This is largely because a lack of information and under-diagnosis overlaps the actual incidence of the disease, which promotes the use of diagnostic tools in reservoirs in order to project the impact of the prevalence of infection on human population.

Table 1 Seroepidemiology Against Trypanosoma cruzi in Mexican Dogs, 2001-2014

\begin{tabular}{|c|c|c|c|c|}
\hline State (City or Municipality) & Seroprevalence in dogs (\%) & Seroprevalence in humans (\%) & Methodology & Reference \\
\hline $\begin{array}{l}\text { Morelos (Cuernavaca) } \\
\text { Puebla (Puebla) }\end{array}$ & $\begin{array}{l}8.8 \\
24.2\end{array}$ & $\begin{array}{l}N D \\
N D\end{array}$ & ELISA & [16] \\
\hline Estado de México (Tlalnepantla) & 1.2 & ND & $\begin{array}{l}\text { ELISA } \\
\text { WB }\end{array}$ & [17] \\
\hline Puebla (Palmar del Bravo) & 10.6 & 4 & $\begin{array}{l}\text { ELISA } \\
\text { IIF }\end{array}$ & [18] \\
\hline $\begin{array}{l}\text { Estado de México } \\
\text { (Tejupilco and Toluca) }\end{array}$ & $\begin{array}{l}21 \\
17.5\end{array}$ & $\begin{array}{l}7.1 \\
\text { ND }\end{array}$ & $\begin{array}{l}\text { IHA } \\
\text { IIF } \\
\text { ELISA }\end{array}$ & [10] \\
\hline $\begin{array}{l}\text { Yucatán } \\
\text { (Tunkas and Mérida) }\end{array}$ & $\begin{array}{l}9.8 \\
17.3\end{array}$ & $\begin{array}{l}N D \\
N D\end{array}$ & $\begin{array}{l}\text { IIF } \\
\text { WB } \\
\text { PCR }\end{array}$ & [19] \\
\hline Chiapas (Tuxtla Gutiérrez) & 4.5 & ND & $\begin{array}{l}\| F \\
W B\end{array}$ & [20] \\
\hline Yucatán (Mérida) & 34 & 8 & $\begin{array}{l}\text { ELISA } \\
\text { IIF } \\
\text { WB }\end{array}$ & [21] \\
\hline Campeche (Campeche) & 7.6 & 0.1 & $\begin{array}{l}\text { ELISA } \\
\text { IIF } \\
\text { WB }\end{array}$ & [22] \\
\hline Estado de México (Tejupilco) & 24.5 & ND & $\begin{array}{l}\text { IHA } \\
\text { ELISA }\end{array}$ & [23] \\
\hline Morelos (Puente Pantitlán) & 24.2 & 1.2 & $\begin{array}{l}\text { ELISA } \\
\text { IIF }\end{array}$ & [24] \\
\hline Estado de México (Toluca) & 0.34 & ND & $\begin{array}{l}\text { IHA } \\
\text { ELISA }\end{array}$ & [25] \\
\hline Jalisco (Teocuitatlán) & 8.1 & ND & $\begin{array}{l}\text { ELISA } \\
\text { WB }\end{array}$ & [26] \\
\hline Sonora (Empalme) & 4.44 & ND & $\begin{array}{l}\text { ELISA } \\
\| F\end{array}$ & This study \\
\hline
\end{tabular}


This study sought to determine the presence of antibodies against T.cruzi in domestic dogs (Canis lupus familiaris) in Sonora, Mexico. This is relevant as a public health issue because this study is the first report about seropositivity in a major domestic reservoir of the disease in a region which, despite being considered endemic, has not seen any governmental actions for controlling and preventing the disease. Sonora is now added to the list of states in Mexico (8 out of 32) that have had studies conducted on the seropositivity in dogs as the main domestic reservoir of $\mathrm{CD}$.

\section{Methods}

\section{Study area and period of sampling}

The study was conducted in the Empalme municipality (110 $48^{\prime} 51^{\prime \prime}$ west latitude and $27^{\circ} 57^{\prime} 42^{\prime \prime}$ north longitude), in the state of Sonora, Mexico (see Fig. 1). Empalme has an area of $503 \mathrm{~km}^{2}$, a height above sea level of $1 \mathrm{~m}$, an average temperature ranging between $17{ }^{\circ} \mathrm{C}$ and $29{ }^{\circ} \mathrm{C}$, and a population of 54,131 inhabitants in 2010, with an average of 3.8 people per dwelling.

There are three well defined geographical zones that correspond with the population's socioeconomic status: 1) a poor area in the northwest near the municipal garbage dump, which is characterized by poor housing and minimum municipal services; 2) the central region, which is characterized by people of median income; and 3) an affluent area in the east and southern regions, which has a population with a high economic status and good housing conditions and municipal services [27].
Sampling was performed during the spring and summer months (May to August) in 2013.

\section{Study population}

Samples were collected from an urban area of the Empalme municipality by selecting dogs at random, regardless of their overall health, age, breed, or sex. The only inclusion criteria were that they resided in the municipality and were pets of responsible owners, defining them as people who fed their dogs and gave consent for their dogs to be sampled.

The sample size was dictated by a specific statistics formula for the detection of a disease in a population with a confidence level of $95 \%$. If in our sample size no animal comes out positive it would mean that the population is free of the disease. Taking into account a 95\% confidence level, an estimated $1.5 \%$ of dogs with $\mathrm{CD}$, and 800 responsible dog owners as the expected total population, the number of required samples was determined to be at least 169. In this study, a total of 180 samples are reported on.

\section{Sample collection}

Blood samples were taken directly from the cephalic vein. To raise this vein, the dorsal region of the foreleg was constrained and disposable $5 \mathrm{ml}$ syringes with $22 \mathrm{G}$ needles (Protec ${ }^{\circ}$, Estado de México, Mexico) on small animals were used to puncture the vein. A double-ended needle plastic plunger and Vacutainer blood collection tubes (BD Vacunainer ${ }^{\bullet}$ Becton, Dickinson and Company,

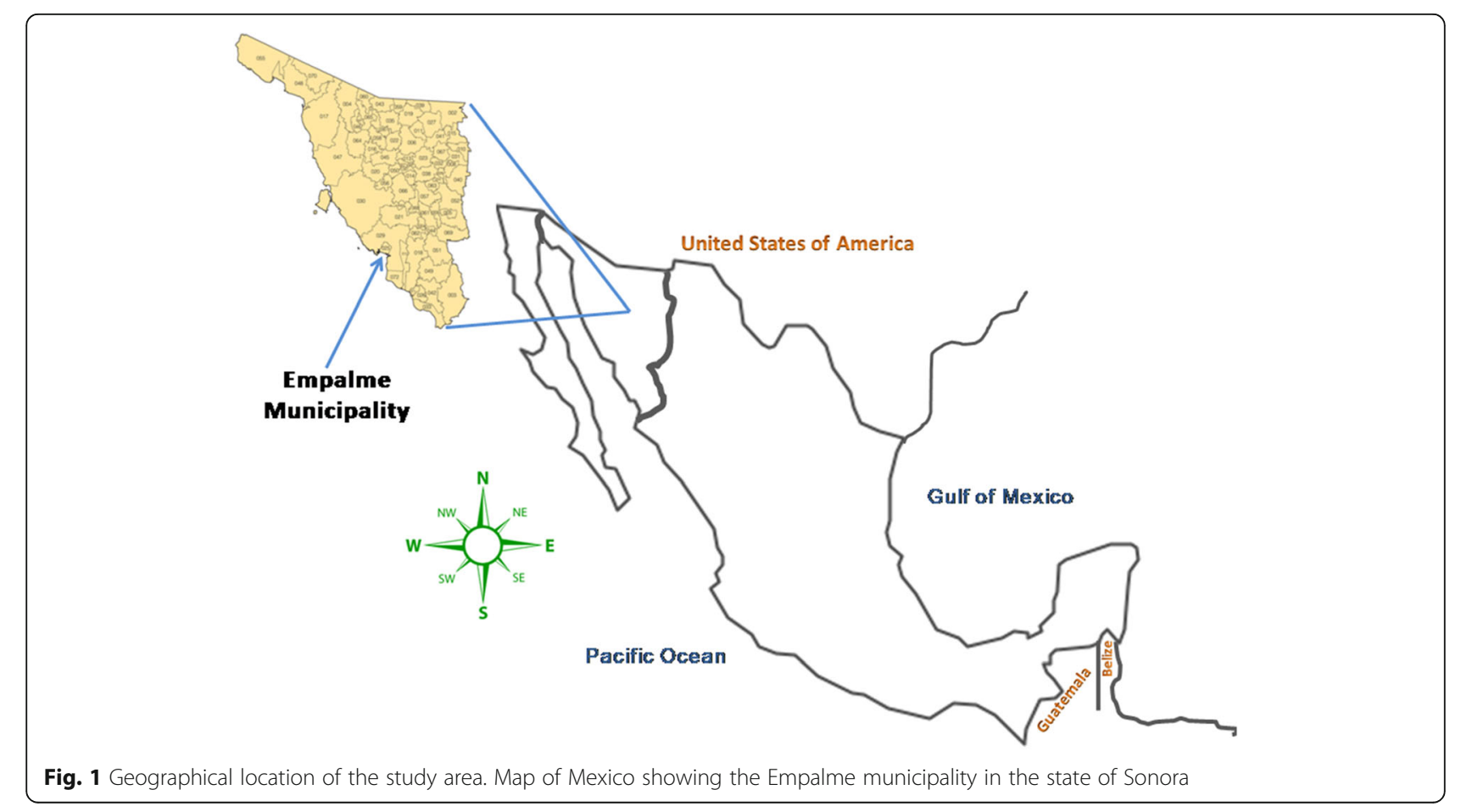


NJ, USA) without anticoagulant were used on larger ones. Subsequently, the clot was removed and the serum was separated by centrifugation at $3000 \mathrm{rpm}$ for seven minutes. Sera were frozen at $-20{ }^{\circ} \mathrm{C}$ until use.

\section{Control sera}

Anti-T. cruzi positive sera from the acute phase of experimental CD were obtained from two Náhuatl dogs. The Náhuatl breed is a Mexican canine inbred, verified, certified, and validated as a biological model by the Mexican Association of Animal Science Laboratory, dated November 25, 2015. The dogs were infected intraperitoneally using a $1.5 \times 10^{6}$ metacyclic trypomastigotes per animal of the Ninoa strain (MHOM/MX/1994/Ninoa), obtained from the urine and feces of infected triatomines and resuspended in saline solution. Animal handling was done following the International Guiding Principles for Biomedical Research Involving Animals and the Norma Oficial Mexicana (NOM-0062-ZOO 1999): Technical Specifications for the Care and Use of Laboratory Animals.

In previous studies, we obtained anti-T. cruzi positive control sera of the chronic phase of CD from dogs inoculated with $2 \times 10^{5}$ metacyclic trypomastigotes of the Ninoa strain (MHOM/MX/1994/Ninoa) [28].

\section{Determination of $T$. cruzi anti-immunoglobulin $\mathrm{G}$ and $\mathrm{M}$ (IgG and IgM) by ELISA}

Anti-T. cruzi antibodies in the 180 dogs were determined using the enzyme-linked immunosorbent assay (ELISA) method described previously [28], with a total extraction of T. cruzi INC-9 isolates (MHOM/MX/2001/ INC9) as an antigen and Goat anti-Canine IgG or IgM Secondary Antibody (Novus Biologicals ${ }^{\circledR}$, CO, USA), as according to the manufacturer's instructions. The mean optical density of seronegative healthy domestic dogs plus three standard deviations were fixed to set the cutoff. All healthy seronegative dogs had values classified as negative after the cut-off value was set.

\section{Indirect immunofluorescence assay}

Reactive ELISA sera were processed by indirect immunofluorescence (IIF) using a method described previously [28]. Positive fluorescence was defined as the detection of green fluorescence on parasites andwas labeled with $+1+$ +++ , according to the fluorescence degree observed using a positive control as the reference point.

\section{Statistical analysis}

The associations between the dogs' ages and sex, and the socioeconomic status pertaining to the geographical area where the dogs live, and the specific antibodies to CD were calculated using chi-square tests with the SPSS program version 15.0 (IL, USA). The level of significance was set at $P \leq 0.05$.

\section{Results}

More than $95 \%$ of the dogs sampled for this study live in homes non-delimited by fences made of solid material; the dwellings only have wooden fences or are surrounded by fences with razor-sharp concertina wire allowing the dogs to roam outside freely. The animals have access to the inside of the house without any restriction; however, they spend the night outdoors in improvised places such as barns, shed or roofed-over areas that protect them from inclement weather. The dogs roam freely on the streets near their homes at any time of day. They do not receive veterinary care and are not covered by a program of preventive immunization. The presence of domestic birds (hens) and/or cats was observed in all dwellings.

The reactive (positive) samples tested by IgG detection using the ELISA method were 19/180 (10.56\%). Of these 19 ELISA reactive samples, 8 (4.44\%) were confirmed as positive when IIF was used as a secondary test. Thus, the seropositivity for T. cruzi in dogs in Empalme was determined to be $4.44 \%(8 / 180)$ by the two tests used (see Table 1).

In order to assess the risk of people being exposed to infected bugs in peridomestic areas based on the detection of IgM in the canine population acting as reservoirs and sentinels, only one sample showed IgM levels above those found in positive control dogs infected experimentally. These data suggest that $0.55 \%$ of dogs sampled showed the acute stage of the disease (Data not shown).

Of the positive samples diagnosed using both tests, five $(62.5 \%)$ were from male dogs and three $(37.5 \%)$ were from female dogs; seven (87.5\%) were mongrels and one (12.5\%) was a bred dog. The eight positive samples confirmed by IIF were sera from puppies (between 0 and 18 months old) and adult dogs (between 18 and 48 months old). Younger dogs compared to older dogs as well as male dogs (5/8) were more likely to be positive for CD. However, the presence of specific antibodies for Chagas infection in dogs from this urban area was not associated with the dogs' age or sex because no statistical differences among these risk factors and the seropositivity rate were found (see Table 2). The geographic area according to the socioeconomic status also did not represent a risk factor for seropositivity for $T$. cruzi infection (8/180) in dogs from this area (see Table 2) $(P \leq 0.05)$.

\section{Discussion}

Large numbers of wild and domestic animals act as reservoirs for T.cruzi infection, however, dogs play a very important role in the prevalence of the disease in the human population because they are the most common mammal found in homes and because they usually come into close contact with their owners. Although cats, pigs, cattle, and other mammals that serve as reservoirs are also in constant contact with humans, it has been demonstrated that 
Table 2 Factors associated with the prevalence of Chagas Disease in Empalme, Sonora, Mexico, 2015

\begin{tabular}{lll}
\hline Factor & Number of dogs $n / 180(\%)$ & $\begin{array}{l}\text { Chagas disease in dogs } \\
\text { by ELISA and confirmatory } \\
\text { IF tests } \\
n / 180 \text { (prevalence } \%)\end{array}$ \\
\hline $\begin{array}{cl}\text { Age } \\
\text { Puppy }\end{array}$ & $106(58.88 \%)$ & $4(2.22 \%)$ \\
Adult & $68(37.77 \%)$ & $4(2.22 \%)$ \\
Geriatric & $6(3.33 \%)$ & $0(0 \%)$ \\
Gender & & $3(1.67 \%)$ \\
Female & $71(39.44 \%)$ & $5(2.78 \%)$ \\
Male & $109(60.56 \%)$ & \\
Economic status by geographic area & $5(2.78 \%)$ \\
Low & $56(31.11 \%)$ & $3(1.67 \%)$ \\
Medium & $78(43.33 \%)$ & $0(0 \%)$ \\
High & $46(25.55 \%)$ & 8 \\
Total dogs & 180 & $4.44 \%$ \\
Percentage & $100 \%$ &
\end{tabular}

ELISA enzyme-linked immuno assay, IIF indirect immunofluorescence test *Difference was considered as significant when $P \leq 0.05$ by Chi-Square test

the presence of dogs in homes can increase the human risk of acquiring parasitosis by up to five times. It is therefore crucial to study the course of $T$. cruzi infection in this species, which can act as sentinels for $\mathrm{CD}$ in this geographic area [15, 28].

Numerous epidemiological studies have been conducted in dogs from the United States to Argentina, in which the presence of specific anti-T. cruzi antibodies has been reported [1, 29-34]. In Mexico, however, few investigations of this type have been conducted (see Table 1).

In this study, a seropositivity of $4.44 \%(8 / 180)$ in domestic dogs (relating to antibodies against T. cruzi) from an urban area in the state of Sonora was determined. In Estado de México, a direct correlation between seropositivity in humans and dogs was observed, with a rate of $7.1 \%$ in humans and $21 \%$ in dogs. In another region of the state, a high percentage of anti-T.cruzi IgG and IgM antibodies in dogs was found (17.5\%), emphasizing the importance of dogs in the transmission route of T. cruzi infection [10]. This has also been observed in Palmar de Bravo, Puebla state, where a presence of $4 \%$ of anti- $T$. cruzi antibodies in humans and $10 \%$ in dogs were found [18]. A seroepidemiological study conducted in Puente Pantitlán, Morelos state reported an anti-T. cruzi seropositivity of $1.2 \%$ in humans and $24.2 \%$ in dogs [24]. The seropositivity rate data from Empalme was very similar to another study conducted in Chiapas (4.5\%), as reported by Jiménez-Coello et al. [20]. Our results are based on the recommendations of the World Health Organization expert committee (2002), which delineate that if positive results are obtained using more than one of the three conventional tests (indirect haemagglutination, IIF, and ELISA), this can be regarded as a definitive diagnosis of T. cruzi infection [35].

In Sonora, 37 positive cases of $\mathrm{CD}$ in humans have been reported up until 2006, with a prevalence of $1.6 \%$ [7]. Although the state is identified as an endemic area, no studies have been conducted on reservoirs for the infection. For this reason, a study on the presence of $T$. cruzi in resident dogs can also offer a strong indication of the current prevalence of infection in the human population.

The seropositivity rate of Chagas infection in dogs was not related to the socioeconomic conditions of the population, nor was it influenced by the age or sex of the animal. These findings correlate with studies conducted by Jimenez-Coello et al. [19] and Martínez et al. [26], both of which were conducted in endemic areas of Mexico. However, positive samples found using the screening test (ELISA) suggest that the economic status of the geographical area may be a potential risk factor in the human and canine populations. This is supported by one dog sample $(1 / 180,0.55 \%)$, showing the acute state of the disease as was demonstrated by the finding of high levels of IgM, the major immunoglobuline produced during a primary immune response, which corresponds to a two-year-old male dog that belongs to an owner residing in the Pesqueira community, a northwestern locality characterized by scarce resources, poor housing conditions, and minimum municipal services, as according to INEGI data [27].

The risk of dogs from a low economic area, such as Empalme, becoming infected is possibly greater than dogs from middle or high economic zones becoming infected, as there are factors that affect the quality of life of inhabitants in these areas, such as poor housing conditions and scarce municipal services, and hence their pets are affected as well. In an endemic area of Panama, significant risk factors for seropositivity for T. cruzi infection were found to be the type of vegetation surrounding the area and the number of domestic animals in a home, while the fitness and sex of the dogs were not found to be significant risk factors [36]. Further studies are however required to prove this hypothesis.

Triatoma recurva has been reported in the Mexican states of Chihuahua, Sonora, and Sinaloa, and has been found in dwellings of inhabitants of the region and in their peridomiciliary environments. The presence of Triatoma rubida and Triatoma longipennis as insects in the process of adaptation to colonize human dwellings and as important transmitter vectors of $\mathrm{CD}$ has been documented in the states of Jalisco, Nayarit, Colima, and Sonora $[37,38]$. For these reasons, we can infer that the presence of antibodies (IgG and 1/180 IgM) against $T$. 
cruzi found in domestic dogs in the study area is due to an active transmission of $T$. cruzi by the vector route. There is also, however, the possibility of congenital transmission in the canine population, as has previously been reported on [28].

Trypanosoma cruzi epidemiology studies in domestic dogs have been performed in seven states of Mexico (see Table 1) and a direct correlation of seropositivity between humans and dogs has been found. In accordance with these data, seropositivity for T. cruzi in dogs in Mexico is 14.24\% on average, while in endemic areas of South America, it ranges from $8 \%$ to $50 \%$ [39]. In all studies conducted in Mexico, including this one, the presence of antibodies for T. cruzi in dogs far exceeds that which is reported for humans, which is also consistent with reports by Gürtler et al. [39]. This may be because dogs are the preferred blood source for insects [40-42] and because dogs are commonly infected orally, a more effective infection route compared to vector transmission that usually occurs in humans [43]. Some border states of the United States have been reported to be endemic areas of the disease, and as Sonora is one of the Mexican states bordering the United States, the data provided in this study show indirect evidence of the presence of the parasite acquired by the vector route through anti- $T$. cruzi antibody detection.

The limitations of this study include the limited number of samples, the fact of not having made the search for antibodies against $T$. cruzi in the owners of the sampled dogs, as well as the study only focusing on a small region.

\section{Conclusions}

This study shows the presence of anti-T. cruzi antibodies in dogs in Sonora, which suggests vector transmission. This demonstrates that in a region with heavy migration, transmission by other means such as transfusion or organ transplantation can play an important part.

This is the first study of its kind conducted in this region of Mexico. Seropositivity for T. cruzi in dogs owned by responsible owners (pets have the minimum conditions of care) was $4.44 \%$, however, this could be higher for homeless dogs or dogs without owners, as these dogs would be more exposed to places where the vector could be present.

There is a need for active surveillance programs throughout the state of Sonora and vector control strategies should be implemented in endemic regions.

\footnotetext{
Abbreviations

CD: Chagas disease; ELISA: Enzyme-linked immunosorbent assay; IgG: Immunoglobulin G; IgM: Immunoglobulin M; IIF: Indirect immunofluorescence
}

\section{Acknowledgements}

Not applicable.

\section{Funding}

This work was not supported by any external funding program. The affiliation institutes' resources were the only ones that financed this study.

\section{Availability of data and materials}

Not applicable.

\section{Authors' contributions}

MA-F and OR-M participated in the concept and direction of the laboratory protocols, analyzed the data, and wrote the paper. RMM-B and JRC-C contributed to the study design, conducted the sample collection, and assisted in the drafting of the paper. SCC-S and MM-C carried out the immunoassays. YAH-D collected the samples and assisted in the drafting of the paper. All authors read and approved the final version of the paper.

\section{Authors' information}

MA-F (PhD), OR-M (PhD, DVM), and SCC-S (Ms) are researchers in medical sciences at the Laboratory of Molecular Immunology and Proteomics, Department of Molecular Biology, National Institute of Cardiology "Ignacio Chávez". RMM-B (PhD, DVM) and JRC-C (Ms, DVM) are professors and researchers at the Department of Agronomic and Veterinary Sciences, Technological Institute of Sonora. MM-C (DVM) and YAH-D (DVM) are undergraduate students from Metropolitan Autonomous University (Mexico City, Mexico) and Technological Institute of Sonora (Ciudad Obregón, Sonora, Mexico), respectively.

\section{Ethics approval and consent to participate}

Informed consent from the dog owners to collect samples was obtained for this study. The experimental protocols were approved by the Bioethics Committee of the Instituto Nacional de Cardiología, Ignacio Chávez.

Consent for publication

Not applicable.

\section{Competing interests}

The authors declare that they have no competing interests.

\section{Author details}

'Department of Molecular Biology, National Institute of Cardiology "Ignacio Chávez", Juan Badiano No. 1, Col. Sección XVI, Delegación Tlalpan, 14080 Mexico City, Mexico. ${ }^{2}$ Department of Agronomics and Veterinary Sciences, Technological Institute of Sonora, 5 de Febrero 818 Sur, Centro, 85000, Cd Obregón, Mexico City, Sonora, Mexico.

Received: 20 September 2016 Accepted: 7 July 2017

Published online: 05 September 2017

\section{References}

1. Waleckx E, Suarez J, Richards B, Dorn PL. Triatoma sanguisuga Blood meals and potential for Chagas disease, Louisiana. USA Emerg Infect Dis. 2012; 2014:2141-3.

2. World Health Organization (WHO). Weekly epidemiological record. 2015;90: 33-44. http://www.who.int/wer/2015/wer9006.pdf?ua=1.

3. Rassi A Jr, Rassi A, Marin-Neto JA. Chagas disease. Lancet. 2010;375:1388-402.

4. Schumunis GA, Yadon ZE. Chagas disease: a Latin American health problem becoming a world health problem. Acta Trop. 2010;115:14-21.

5. Tarleton RL, Gürtler RE, Urbina JA, Ramsey J, Viotti R. Chagas disease and the London declaration on neglected tropical diseases. PLoS Negl Trop Dis. 2014;8:e3219. doi:10.1371/journal.pntd.0003219.

6. Requena-Méndez A, Aldasoro E, de Lazzari E, Sicuri E, Brown M, Moore DA, et al. Prevalence of Chagas disease in Latin-American migrants living in Europe: a systematic review and meta-analysis. PLoS Negl Trop Dis. 2015;9: e0003540. doi:10.1371/journal.pntd.0003540.

7. Cruz-Reyes A, Pickering-Lopez JM. Chagas disease in Mexico: an analysis of geographical distribution during the past 76 years-a review. Mem Inst Oswaldo Cruz. 2006;101:345-54.

8. Instituto Nacional de Estadística y Geografía. México en cifras. http://www. beta.inegi.org.mx/app/areasgeograficas/?ag=00. Accessed 5 Jun 2013.

9. Carabarin-Lima A, González-Vázquez MC, Rodríguez-Morales O, Baylón-Pacheco L, Rosales-Encina JL, Reyes-López PA, et al. Chagas disease (American trypanosomiasis) in Mexico: an update. Acta Trop. 2013;127:126-35.

10. Estrada-Franco JG, Bhatia V, Diaz-Albiter H, Ochoa-Garcia L, Barbabosa A, Vazquez-Chagoyan JC, et al. Human Trypanosoma cruzi infection and seropositivity in dogs. Mexico Emerg Infect Dis. 2006;12:624-30. 
11. Barr SC, Schmidt SP, Brown CC, Klei TR. Pathologic features of dogs inoculated with north American Trypanosoma cruzi isolates. Am J Vet Res. 1991;52:2033-9.

12. Meurs KM, Anthony MA, Slater M, Miller MW. Chronic Trypanosoma cruzi infection in dogs: 11 cases (1987-1996). J Am Vet Med Assoc. 1998;213:497-500.

13. Martínez-Ibarra JA, Valencia-Navarro I, León-Saucedo S, Ibáñez-Cervantes G, Bustos-Saldaña R, Montañez-Valdez OD, et al. Distribution and infection of triatomines (Hemiptera: Reduviidae) by Trypanosoma cruzi in the state of Michoacán. México Mem Inst Oswaldo Cruz. 2011;106:445-50.

14. Bargues MD, Klisiowicz DR, Gonzalez-Candelas F, Ramsey JM, Monroy C, Ponce $\mathrm{C}$, et al. Phylogeography and genetic variation of Triatoma dimidiata, the main Chagas disease vector in central America, and its position within the genus Triatoma. PLoS Negl Trop Dis. 2008;2:e233. doi:10.1371/journal. pntd.0000233

15. Turriago B, Vallejo G, Guhl F. Seroprevalencia de T. cruzi en perros de dos áreas endémicas de Colombia. Revista Med 2008;16:11-8.

16. García-Vazquez Z, Rosario-Cruz R, Miranda-Miranda E, Dominguez-Marquez A. A serological survey of Trypanosoma cruzi infection in dogs of two urban areas of Mexico. Preventive Veterinary Medicine. 1995;25:I-6. in Spanish

17. Campos-Valdéz G, Barrera-Peña R, de la Luz SR. Dra. Jiménez-Cardoso E, Martínez-Labat P. Anti-Trypanosoma cruzi antibodies in dogs (Canis familiaris) from Tlalnepantla municipality, state of Mexico. BIOQUIMIA. 2001;26:16-9.

18. Sosa-Jurado F, Zumaquero-Ríos JL, Reyes PA, Cruz-García A, Guzmán-Bracho C, Monteón VM. Factores bióticos y abióticos que determinan la seroprevalencia de anticuerpos contra Trypanosoma cruzi en el municipio de Palmar de Bravo, Puebla. México Salud Publica Mex. 2004;46:39-48. (in Spanish)

19. Jimenez-Coello M, Poot-Cob M, Ortega-Pacheco A, et al. American trypanosomiasis in dogs from an urban and rural area of Yucatán, Mexico. Vector Borne Zoonotic Dis. 2008;8:755-61.

20. Jimenez-Coello M, Ortega-Pacheco A, Guzman-Marin E, Guiris-Andrade DM, Martinez-Figueroa L, Acosta-Viana KY. Stray dogs as reservoirs of the zoonotic agents Leptospira interrogans, Trypanosoma cruzi, and Aspergillus spp. in an urban area of Chiapas in southern Mexico. Vector Borne Zoonotic Dis. 2010;10:135-41.

21. Jiménez-Coello M, Guzmán-Marín E, Ortega-Pacheco A, Acosta-Viana KY. Serological survey of American trypanosomiasis in dogs and their owners from an urban area of Mérida Yucatán. México Transbound Emerg Dis. 2010; 57:33-6.

22. Balan LU, Yerbes IM, Piña MA, Balmes J, Pascual A, Hernández O, Lopez R, et al. Higher seroprevalence of Trypanosoma cruzi infection in dogs than in humans in an urban area of Campeche. Mexico Vector Borne Zoonotic Dis. 2011;11:843-4.

23. Barbabosa-Pliego A, Gil PC, Hernández DO, Aparicio-Burgos JE, de OcaJiménez RM, Martínez-Castañeda JS, et al. Prevalence of Trypanosoma cruzi in dogs (Canis familiaris) and triatomines during 2008 in a sanitary region of the state of Mexico, Mexico.Vector Borne Zoonotic Dis. 2011;11:151-156.

24. Portugal-García C, García-Vásquez Z, Monteón-Padilla V, Chávez-López V, Olamendi-Portugal M, Ramos C. Anticuerpos contra Trypanosoma cruzi en humanos y perros y presencia del parásito en Meccus pallidipennis en la localidad de Puente Pantitlán, Morelos. México Rev Biomed. 2011;22:67-75. (in Spanish)

25. Quijano-Hernández IA, Castro-Barcena A, Barbabosa-Pliego A, Ochoa-García L, Del Ángel-Caraza J, Vázquez-Chagoyán JC. Seroprevalence survey of American trypanosomiasis in Central Valley of Toluca. ScientificWorld Journal 2012; 450619. doi:10.1100/2012/450619.

26. Martínez I, Martínez-Ibarra A, Arce-Fonseca M, Rodríguez-Morales O, PérezMorales D, Reyes López PA, et al. Seroprevalence and major antigens recognized by sera from Trypanosoma cruzi-infected dogs from Jalisco. México Rev Argent Microbiol. 2014;46:85-90.

27. Instituto Nacional de Estadística y Geografía. Marco Geoestadístico Nacional. Catálogo de Claves de Entidades Federativas, Municipios y Localidades.2010. Entidad 26 Sonora, Página 125. http://www.inegi.org.mx/geo/contenidos/ geoestadistica/CatalogoClaves.aspx. Accessed 5 Jun 2013. (in Spanish).

28. Rodríguez-Morales O, Ballinas-Verdugo MA, Alejandre Aguilar R, Reyes PA, Arce Fonseca M. Trypanosoma cruzi connatal transmission in dogs with Chagas disease: experimental case report. Vector Borne Zoonotic Dis. 2011; 11:1365-70

29. Reyes L, Salesky E, Cerdas C. Presencia de anticuerpos contra Trypanosoma cruzi en perros de Costa Rica. Parasitol Latinoam. 2002;57:66-8.

30. Roque AL, Xavier SC, Gerhardt M, Silva MF, Lima VS, D'Andrea PS, et al. Trypanosoma cruzi among wild and domestic mammals in different areas of the Abaetetuba municipality (Pará state, Brazil), an endemic Chagas disease transmission area. Vet Parasitol. 2013;193:71-7.

31. Tenney TD, Curtis-Robles R, Snowden KF, Hamer SA. Shelter dogs as sentinels for Trypanosoma cruzi transmission across Texas. Emerg Infect Dis. 2014;20:1323-6.

32. Enriquez GF, Bua J, Orozco MM, Wirth S, Schijman AG, Gürtler RE, et al. High levels of Trypanosoma cruzi DNA determined by qPCR and infectiousness to Triatoma infestans support dogs and cats are major sources of parasites for domestic transmission. Infect Genet Evol. 2014;25:36-43.

33. Chikweto A, Kumthekar S, Chawla P, Tiwari KP, Perea LM, Paterson T, et al. Seroprevalence of Trypanosoma cruzi in stray and pet dogs in Grenada. West Indies Trop Biomed. 2014;31:347-50.

34. Cantillo-Barraza O, Garcés E, Gómez-Palacio A, Cortés LA, Pereira A, Marcet PL, et al. Eco-epidemiological study of an endemic Chagas disease region in northern Colombia reveals the importance of Triatoma maculata (Hemiptera: Reduviidae), dogs and Didelphis marsupialis in Trypanosoma cruzi maintenance. Parasit Vectors. 2015;8:482. doi:10.1186/s13071-015-1100-2.

35. World Health Organization, Technical Report Series, 2002. Control of Chagas disease. second report of the WHO expert committee. Geneva: World Health Organization; 1-109.

36. Saldaña A, Calzada JE, Pineda V, Perea M, Rigg C, González K, et al. Risk factors associated with Trypanosoma cruzi exposure in domestic dogs from a rural community in Panama. Mem Inst Oswaldo Cruz. 2015;110:936-44.

37. Licón TA. Infección de Triatoma recurva por Trypanosoma cruzi en un campamento minero de Urique, Chihuahua (México). RESPYN. 2006;7 http://respyn.uanl.mx/vii/3/articulos/urique-b.htm. Accessed 5 Jun 2015

38. Salazar-Schettino PM, Rojas-Wastavino G, Cabrera-Bravo M, Bucio-Torres MII, Martínez-lbarra JA, Monroy-Escobar MC, et al. A revision of thirteen species of Triatominae (Hemiptera: Reduviidae) vectors of Chagas disease in Mexico. J Selva Andina Res Soc. 2010;1:57-80.

39. Gürtler RE, Cecere MC, Lauricella MA, Cardinal MV, Kitron U, Cohen JE. Domestic dogs and cats as sources of Trypanosoma cruzi infection in rural northwestern Argentina. Parasitology. 2007;134:69-82.

40. Calderón-Arguedas O, Chinchilla M, García F, Vargas M. Preferencias alimentarias de $T$. dimidiata (Hemiptera: Reduviidae) procedentes de la Meseta Central de Costa Rica a finales del siglo XX. Parasitol Día. 2001;25: 76-81. (in Spanish)

41. Calderón-Arguedas O, Troyo A, Castro A, Guerrero O, Chinchilla M. Infestación por vectores de la Enfermedad de Chagas en cuatro zonas endémicas de la meseta central de Costa Rica. Parasitol Latinoam. 2002;57: 88-95. (in Spanish)

42. Mota J, Chacon JC, Gutiérrez-Cabrera AE, et al. Identification of blood meal source and infection with Trypanosoma cruzi of Chagas disease vectors using a multiplex cytochrome b polymerase chain reaction assay. Vector Borne Zoonotic Dis. 2007;7:617-27.

43. Montenegro VM, Jimenez M, Dias JC, Zeledon R. Chagas disease in dogs from endemic areas of Costa Rica. Mem Inst Oswaldo Cruz. 2002;97:491-4

\section{Submit your next manuscript to BioMed Central and we will help you at every step:}

- We accept pre-submission inquiries

- Our selector tool helps you to find the most relevant journal

- We provide round the clock customer support

- Convenient online submission

- Thorough peer review

- Inclusion in PubMed and all major indexing services

- Maximum visibility for your research

Submit your manuscript at www.biomedcentral.com/submit 